the homosexual (who, however haphazardly or contradictorily constituted, is a discursive formation whose presence can be located in the archive), nothing in this passage forecloses this effort. The term queer was, at least initially, reinvented to refer to a subject other than the nineteenth-century homosexual.

Note that, contra his unhistoricist critics, Foucault does not employ the term identity to define a personage. Rather, he uses difference to do so-the difference between a juridical subject and a disciplinary one, between a subject constituted by religious prohibitions and the subject of the science of sexuality. For some reason Robert Hurley, in his translation of the same passage, placed a comma rather than a colon after personage (History of Sexuality: An Introduction [Vintage, 1990; print] 43). This is not a minor alteration. Personage here is shorthand for the new kind of subject Foucault is struggling to define.

One of the basic tenets of structural linguistics is that language is a system of differences with no positive terms. Homosexual finds one of its conditions of meaning in its difference from sodomite. The fact that both words existand circulate in different discursive contextssuggests their difference from each other.

Finally, in this passage Foucault is not interested in the disappearance of the sodomitesomething he never says occurred-nor does he imply that the sodomite and homosexual have no relation to each other. $\mathrm{He}$ is, rather, interested in the historical emergence of the homosexual as a discursive category. The contemporary Christian invocation to "hate the sin and not the sinner" is discursive evidence of the sodomite and his continuing life in the present. The endless return to this passage in Foucault suggests queer studies' investment, for all its claims to the contrary, in identity politics, an investment that is one of the field's historical conditions of possibility as an academic discipline.

Unfortunately, the unhistoricist emphasis on homo as sameness threatens to replicate the fantasy that desire is about the securing of "real" bodies and relations. There is nothing intrinsically homo about the homosexual, and queer is often deployed as a nagging reminder of this. For those of us queers whose subjectivities were structured, long before we were capable of any kind of unconscious embracing of epithets, by insults like fag, fairy, homo, and bull dyke, our homo desire is inextricably wedded to our gender dysfunction and our inability to figure out if our sexual partners are in fact same, other, or something else. Given the hardfought years of learning to love the (wo)man in me, I am not yet willing to give up the admittedly fatiguing project of attempting to think difference in nonhierarchical terms, perhaps even the nonbinary terms that Robyn Wiegman calls “triangular” in "Eve's Triangles: Queer Studies beside Itself" (Reading Eve Sedgwick: A Collection of Essays, ed. Michael O'Rourke [Palgrave, forthcoming]). My (always provisional) knowledge of history, however, and of the ways in which male privilege has sometimes been underwritten by fantastic identifications with the feminine, troubles my own attempts to finish even these brief comments.

John Champagne

Penn State University, Erie-Behrend

\section{Jonathan Safran Foer and the Impossible Book}

\section{To THE EDITOR:}

In "Combining Close and Distant Reading: Jonathan Safran Foer's Tree of Codes and the Aesthetic of Bookishness" (128.1 [2013]: 226-31), N. Katherine Hayles bookends some (useful!) Morettian word counting with a close examination of Foer's die-cut book as one of a number that "are fighting back" against "the epochal shift from print to digital texts," insisting that the "bodies" of printed books offer something mere information cannot (226).

(C) 2013 PAUL ARDOIN

PMLA 128.4 (2013), published by the Modern Language Association of America 
For Hayles Tree of Codes, which Foer created by taking Bruno Schulz's Street of Crocodiles and cutting out most of the text, is like books by Mark Danielewski, Anne Carson, and B. S. Johnson that "engage in strategies that entice readers to become intimate with the novels' bodies through physical manipulations of their printed forms" and seek to "reawaken passion by introducing novelty into what have become routine physical encounters." Quoting Jessica Pressman, Hayles calls this an "aesthetic of bookishness" (227). Hayles is not wrong-the delicate Tree of Codes, in particular, is part of a recent line from Visual Editions, which also reprints Marc Saporta's boxed book, Composition No. 1, and a newly redesigned version of the famously experimental Tristram Shandy, which Hayles cites as an early deconstruction of the book. The publisher's most recent book, Adam Thirlwell's Kapow!, might be of particular interest to Hayles, with its footnotes reminiscent of concrete poetry, forming unexpected shapes and trailing onto foldout pages.

A possible complication to Hayles's argument, however, runs throughout Foer's body of work, including Tree of Codes: Foer's experiments, physical and formal, continue the project of the impossible book, present as early as Everything Is Illuminated. That novel features The Book of Antecedents, a fictional history that is "continually updated" in an attempt to traverse the mimetic gap between itself and its subject matter. "The full-time committee" in charge of composing and updating (the two projects merge- a condition familiar to readers of blogs, updated or corrected online news stories, or most any nondead Web site) begins to record even its own "reporting, just to keep the book moving, expanding, becoming more like life: We are writing ... We are writing... We are writing..." ([Harper, 2003; print] 196). This goes on for pages (in both The Book of Antecedents and Everything Is Illuminated).

Through the lens of Foer's entire body of work, one could read Tree of Codes as being about the impossibility of finished representation, as well as the failure of any inscription- particularly the printed book-to do anything more than represent itself, making the physical book a sort of monument to its own useless materiality. It's a Beckettian project, really-I can't go on, I'll go on-making the hole boring of Tree of Codes less a celebration of a potentially "reawaken[ed] passion" than a physical manifestation of the work of the "huge black pauses" Beckett heard in Beethoven and sought to replicate in text. Beckett's letter to Axel Kaun on the matter complains of the "terrifyingly arbitrary materiality of the word surface" (9 July 1937; The Letters of Samuel Beckett; vol. 1 [1929-40]; ed. Martha Dow Fehsenfeld and Lois More Overbeck; trans. Viola Westbrook [Cambridge UP, 2009; 516-21; print] 518-19). If language is doomed to fail in its attempts to do justice to a real state of being obscured by the material, how much less likely is the oh-so-material printed book to do so? The materially fascinating Tree of Codes may be out to remove as much of the material as possible, making its passionawakening, book-celebrating, material novelty a mere side effect of a larger project.

The idea of removal puts me in mind of another author Hayles mentions-Mark Z. Danielewski. Hayles cites Only Revolutions, a Danielewski book that requires the reader to rotate it periodically and alternate between reading it front to back and back to front. Danielewski's more famous House of Leaves could be cited for the physical response demanded by its own twisting text. Again, though, we cannot make even Danielewski an uncomplicated practitioner of the aesthetic of bookishness when we look across his body of work. His novella The Fifty Year Sword, for example, charming and clever as it is on the page, is much more elaborately designed in its iPad e-book version, where letters blur in and out of focus or disappear from the screen. With Danielewski there seems to be less an inherent loyalty to or celebration of the material, printed book than a desire to push the boundaries of written narratives.

Pushing those boundaries is also the primary work of Foer's short story "About the Typefaces Not Used in This Edition," which 
uses none of the innovative display features that are the sole focus of its content. The opening words of the story are "ELENA, 10 POINT," followed by a description of a make-believe typeface by this name that sees frequently used words begin to fade and fall apart over time (The Guardian; Guardian News and Media, 6 Dec. 2002; Web; 22 Aug. 2013). The premise of "About the Typefaces" is that there is no edition, no original book. What readers get instead is the story of the fonts that were not used in the book that does not exist. There is, without a doubt, a clear appreciation of what the material text might do, but there is also the implicit acknowledgment of how much the material text cannot do. While a book may age and crumble, select printed words on the page cannot do so on cue. While a line of text might begin to contain its own alternate versions (as in Joyce's layered Finnegans Wake, Nicholson Baker's and David Foster Wallace's elaborate footnoting, and the children's-book series Choose Your Own Adventure), the material book could never replicate the work of Foer's imagined "TRANS-1, 10 POINT" typeface, which sees words linger for a moment and then be replaced by synonyms, which recombine for new meaning. And what an aesthetic of bookishness can never give us, but "About the Typefaces" insists on imagining, is a typeface like the imaginary "REAL TIME, REAL WORLD, TO SCALE," which, the speaker tells us, "began organically, with the popularization of e-mail" and its reshaping of language and punctuation into unpronounceable (but still somehow Saussure-defying) emoticons :)

Paul Ardoin

Florida State University

\section{Black Print Culture before Plessy}

\section{To THE EDITOR:}

The recent cluster of responses to Kenneth W. Warren's What Was African American Literature? (128.2 [2013]: 386-408) offered some useful reflection on the question, to use Rafia Zafar's skillful reframing of the book's title, "What purpose is served by proposing an end to African American literature?" (401).

I was thus stunned by the participants' lack of attention to a key corollary question: what purpose is served by proposing a beginning to African American literature-especially a beginning as late as Plessy v. Ferguson (1896)?

Relying on the ahistorical sense that pre1896 black literature was more interested in reaching white readers, this start date ironically positions the literature of the Jim Crow era as similarly reactive. Several recent critics, especially those influenced by Frances Smith Foster's work, have demonstrated the development of pockets of lively black print culture-by African Americans, largely for African Americans, and often centered on concerns of African Americans-decades before Plessy. That print culture defies many Americanists' reductive tokenizing of Phillis Wheatley, Olaudah Equiano, Frederick Douglass, and Harriet Jacobs-part of the still common dismissal of much "pre-Harlem" black writing - and it demands that we rethink the aesthetic and political dimensions of periodization and canon formation. The nineteenth century (to say nothing of the eighteenth) was and is much richer and messier than its absence in Warren's book and much of the PMLA response suggests.

Eric Gardner Saginaw Valley State University

(C) 2013 ERIC GARDNER

PMLA 128.4 (2013), published by the Modern Language Association of America 